\title{
Effects of Calcium Silicate Fertilization on Disease Intensity and Yield and Quality of Rice Grain
}

ISSN: 2637-7659

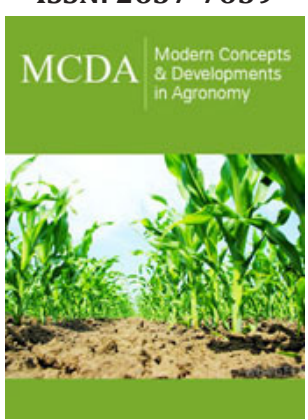

*Corresponding author: Leandro José Dallagnol, Department of Crop Protection, Federal University of Pelotas, Pelotas, Brazil

Submission: 啙 March 24, 2021

Published: 此April 08, 2021

Volume 8 - Issue 3

How to cite this article: Juan Felipe Rivera, Henrique da Silva Silveira Duarte, Keilor da Rosa Dorneles, Paulo Cesar Pazdiora, Nathan Levien Vanier, Leandro José Dallagnol. Effects of Calcium Silicate Fertilization on Disease Intensity and Yield and Quality of Rice Grain. Mod Concep Dev Agrono. 8(3). MCDA. 000688. 2021. DOI: 10.31031/MCDA.2021.08.000688

Copyright@ Leandro José Dallagnol. This article is distributed under the terms of the Creative Commons Attribution 4.0 International License, which permits unrestricted use and redistribution provided that the original author and source are credited.
Juan Felipe Rivera ${ }^{1}$, Henrique da Silva Silveira Duarte ${ }^{2}$, Keilor da Rosa Dorneles ${ }^{1}$, Paulo Cesar Pazdiora ${ }^{1}$, Nathan Levien Vanier ${ }^{3}$ and Leandro José Dallagnol ${ }^{1 *}$

${ }^{1}$ Department of Crop Protection, Federal University of Pelotas, Pelotas, Brazil

${ }^{2}$ Department of Crop Production and Protection, Federal University of Parana, Curitiba, PR Brazil

${ }^{3}$ Department of Agroindustrial Science and Technology, Federal University of Pelotas, Pelotas, Brazil

\begin{abstract}
Rice (Oryza sativa L.) is a strategic crop for food security, with significant economic importance for many countries. Silicon (Si) is a mineral element that increases both rice resistance to diseases and yield. In this study we evaluated, in two crop seasons, the effect of calcium silicate (source of $\mathrm{Si}$ ), incorporated in the soil, on disease control, grain yield and its quality on three rice cultivars grown in flooded soils in Rio Grande do Sul, Brazil. The leaf diseases only occurred at the end of the crop cycle and in low intensity. Plants grown on plots supplied with calcium silicate showed higher concentration of Si in leaves and lower intensity of two diseases (brown spot and leaf scald), but without significant effect on grain yield and on quality parameters (brown rice content, head rice yield and translucent rice content). Grain yield and quality parameters were only affected by cultivars. In conclusion, calcium silicate fertilization did not influence grain yield and its quality under low intensity and / or occurrence of biotic stress in final development stages of the plant.
\end{abstract}

Keywords: Disease control; Oryza sativa; Rice quality; Silicon

Introduction

Rice (Oryza sativa L.) is one of the most widely grown and consumed cereals worldwide, and estimates are that demand will increase by $60 \%$ in 2050 [1]. Brazil is the ninth-largest rice-producing country, the largest outside Asia, with 11.75 million t in 2018, which represented approximately $1.5 \%$ of the world's rice production [1,2]. The southern region of Brazil is responsible for $82 \%$ of Brazil's rice production, mainly the states of Rio Grande do Sul (71.5\%) and Santa Catarina (9.2\%) [2]. Widely divergent environments, such as irrigated uplands and lowlands, flooded and rainfed lowlands, and rainfed upland ecosystems, are used to grow rice. In Brazil, rice production occurs predominantly in flooded lowlands, which are mainly Hydromorphic Planosol in the Rio Grande do Sul State [3]. Rice plant is susceptible to pathogens that may compromise it development and production by lowering the number and weight of grains and reducing grain nutritional quality by lowering the contents of carbohydrates and/or proteins [4,5]. The main diseases affecting rice plants in Brazil are blast (Magnaporthe oryzae Hebert), brown spot (Cochliobolus miyabeanus Ito \& Kuribayashi), leaf scald (Monographella albescens Thuemen) and sheath blight (Thanatephorus cucumeris Frank) [6]. Resistant cultivars, healthy seeds and fungicide application are the main control alternatives used to manage these rice diseases [6-8]. A control measure that is gaining attention worldwide is the application of silicon (Si) fertilizer. Rice plants can accumulate Si up to $10 \%$ of dry weight [9], which was been associated to alleviation of abiotic stresses such as nutrient imbalance, salinity, drought and heavy metals as well as enhancing resistance against diseases and pests [10-15]. Although silicate minerals are dominant soil components, the available silicic acid may be scarce to plant uptake particularly in croplands due to continuous Si removal with crop harvest [16] becoming Si fertilization an option to increase plant's resistance to biotic and abiotic stresses and gain on yield. In this study we evaluated the effects of calcium silicate (a Si source) fertilization on diseases intensity, and yield and quality of grains produced by rice plants grown on flooded soil in Rio Grande do Sul, Brazil. 


\section{Material and Methods}

Experimental area, rice cultivars and climatical measurements. The experimental area used in the experiment is located in the

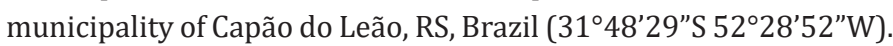
The soil of the experimental area is classified as solodic eutrophic Hydromorphic Planosol with the characteristics as follows: $\mathrm{pH}$ water $(1: 1)=5.2$; CEC pH 7=7.1 cmolc; organic matter $=1.38 \%$; clay $=25 \%$;

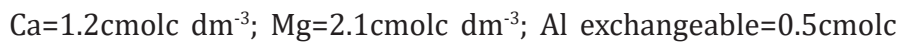
$\mathrm{dm}^{-3} ; \mathrm{P}$ available $=8.1 \mathrm{mg} \mathrm{dm}^{-3} ; \mathrm{K}$ exchangeable $=39 \mathrm{mg} \mathrm{dm}^{-3}$. The concentration of available $\mathrm{Si}$ (extracted with $0.01 \mathrm{M} \mathrm{CaCl}_{2}$ ) in the soil was $14.0 \mathrm{mg} \mathrm{dm}^{-3}$. The experimental area was previously used for rice cultivation, but at the time of installation of the experiment it was two years of fallow.

Seeds from the rice cultivars BRS Querência (Embrapa), BRS Atalanta (Embrapa), and Puitá INTA CL (BASF S/A) were used for experiment. The grain produced by these three genotypes are categorized as long slender and high amylose. Data on average rainfall, air humidity, and maximum and minimum daily temperatures were obtained from the Terras Baixas Meteorological Station of the Brazilian Agricultural Research Corporation (Embrapa) in Capão do Leão, RS (31 $48^{\prime} 12^{\prime \prime}$ S, 52 $2^{\circ} 4^{\prime} 40^{\prime \prime} \mathrm{W}$-altitude of $13.24 \mathrm{~m})$.

\section{Experimental design}

A randomized $3 \times 2$ factorial block design was used (three cultivars and two calcium silicate treatments - without (-Si) or with $(+\mathrm{Si}))$, with four replications. Each replication consisted of $10 \mathrm{~m}^{2}$ $(2 \times 5 \mathrm{~m})$. The experimental units were separated from each other by $100 \mathrm{~cm}$ and surrounded by a ridge $(40 \mathrm{~cm}$ tall and $60 \mathrm{~cm}$ wide). The experiment was conducted twice (2016-17 and 2017-18 crop seasons).

\section{Soil management}

The calcium silicate (Agrosilício Plus $®$ ), which was composed of $25.0 \%$ calcium, $6.0 \%$ magnesium and $10.5 \% \mathrm{Si}$, was applied at a rate of 4.9 tons ha $^{-1}$. To standardize the amount of calcium and magnesium supplied to the plants in the calcium silicate treatment, soil of the control treatment was amended with limestone, composed of $26.5 \%$ calcium and $15.0 \%$ magnesium, at a rate of 4.1 tons ha $^{-1}$. Calcium silicate or limestone was incorporated in the soil using a rotary hoe 30 days before sowing. In the second year (experiment repetition), the products were applied again to keep the soil $\mathrm{pH}$ at 6.5. Fertilization with nitrogen, phosphorus and potassium, flooding management and other crop practices were carried out according to the recommendations for flooded rice cultivation [6].

\section{Biotic stress assesses}

The assessment of diseases was initiated after seedling emergence and repeated weekly until harvesting. The intensity of diseases (blast, brown spot, eyespot (Drechslera gigantea) and leaf scald) was recorded during the reproductive stage. For disease assessment, the severity (percentage of total leaf area affected by each disease) was evaluated on all flag leaves of 12 marked plants, systematically positioned inside each plot to represent as best as possible the area of the replication. Leaf blast was assessed using a 10-level scale [17]; brown spot was assessed using a 7-level scale [18]; leaf scald was assessed using a 6-level scale [19]; and eyespot was assessed using a 7-level diagram [20]. Disease severity data were plotted to obtain the disease progress curves and the area under disease progress curve (AUDPC) was calculated according to Shaner [21].

\section{Determination of yield and grain quality}

The rice grains were harvested from each plot when the moisture content was approximately 22\% . Grains were then subjected to cleaning and drying processes until 13\% moisture content was achieved. Afterwards, rice yield was estimated and expressed as $\mathrm{kg} \mathrm{ha}^{-1}$. The brown rice content and the head rice yield were determined according to the Brazilian Rice Regulation [22]. For this, rice samples (100g) were subjected to husking and milling using a Zaccaria Rice Machine. Subsequently, the polished kernels were placed in the trieur component of the same machine where the broken kernels were separated from the whole kernels. Broken kernels were those with a length lower than $3 / 4$ parts of the minimum length of $6.0 \mathrm{~mm}$ accepted for long grains, i.e., less than $4.49 \mathrm{~mm}$ [22]. The brown rice content and head rice yield were expressed as percentages. The polished rice samples were subjected to chalky and translucent grain identification and separation. For each sample, totally translucent grains were weighed, and their percentage was calculated.

\section{Leaf silicon quantification}

In the last assessment of diseases, the flag leaves were sampled and used to determine the Si concentration. Briefly, samples were rinsed with deionized water, dried for 72 hours at $70{ }^{\circ} \mathrm{C}$ and ground to pass through a 40 -mesh screen using a mill. The percentage of $\mathrm{Si}$ was determined from $0.1 \mathrm{~g}$ of leaf tissue using the yellow method with sodium hydroxide and hydrogen peroxide [23].

\section{Data analysis}

The Shapiro-Wilk test was applied to verify the normality of the data, and the Cochran's test, was used to assess homoscedasticity. Further, data were subjected to analysis of variance (ANOVA) and the means were compared by the Student $t$-test $(\mathrm{P}<0.05)$ or Tukey test $(\mathrm{P}<0.05)$. The statistical analyses were performed using $\mathrm{R}$ software [24].

\section{Results and Discussion}

The cultivars and calcium silicate fertilization were significant for some variables, but the interaction of factors was not significant $(\mathrm{P}<0.05)$ for all variables. The concentration of $\mathrm{Si}$ in leaves was only influenced $(\mathrm{P}<0.05)$ by calcium silicate treatment, increasing $10 \%$ in leaves of plants grown in flooded soil fertilized (Figure 1a).

In the 2016-17 crop season, the occurrences of brown spot, leaf scald and blast were recorded. These diseases occurred only in the reproductive stage, and their progress was affected by cultivar and calcium silicate fertilization, especially for those that occurred earlier such as brown spot (Figure 1c) and leaf scald (Figure 1d), 
but not blast (Figure 1b), which occurred at the end of the crop cycle with low severity. Calcium silicate fertilization reduced the AUDPC values by 16.5 and $14.3 \%$ for brown spot (Figure 1c) and leaf scald (Figure 1d), respectively. Eyespot was recorded on BRS Querencia and BRS Atalanta with severity below than $0.5 \%$, regardless of $\mathrm{Si}$ treatment (data not shown).
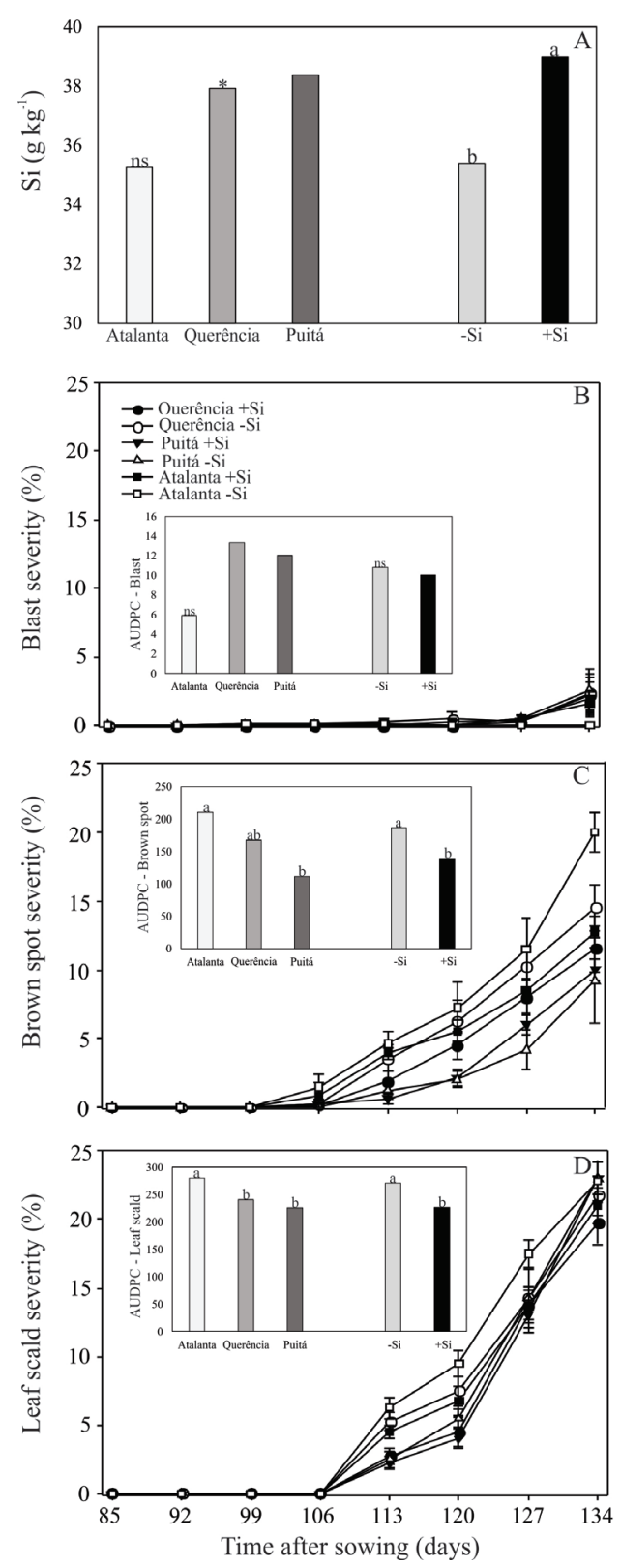

Among the cultivars, the lowest AUDPC value for brown spot (Figure 1c) was recorded in the cultivar Puitá INTA CL, and for leaf scald (Figure 1d) the lowest AUDPC value was recorded in the cultivars BRS Querência and Puitá INTA CL.
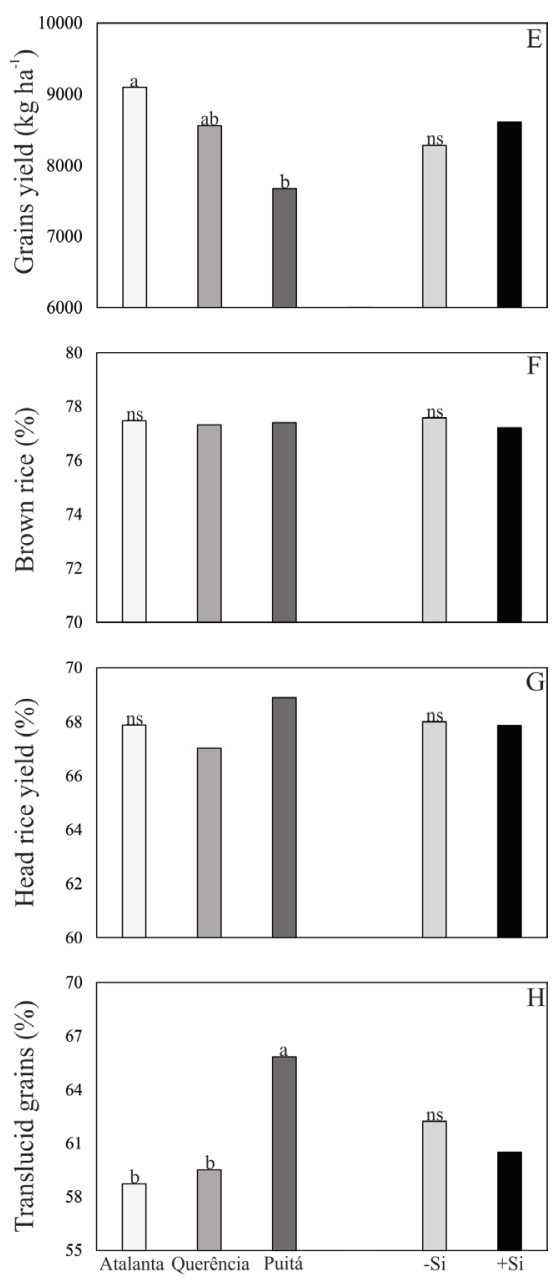

Figure 1: Leaf silicon ( $\mathrm{Si})$ concentration (A), progress curve of the severity of blast (B), brown spot (C) and leaf scald $(\mathrm{D})$, grain yield $(\mathrm{E})$, brown rice $(\mathrm{F})$, head rice yield $(\mathrm{G})$ and translucent grains $(\mathrm{H})$ of rice plants of the cultivars BRS Querência, Puitá INTA CL and BRS Atalanta, grown in flooded soil containing calcium silicate (+Si) or limestone (-Si). For each disease is showed the area under disease progress curve (AUDPC) inside each figure. Data of the two crop seasons are combined in Figures A, E, F, G and H. Data in Figures B, C and D are from the 2016-17 crop season. *means followed by distinct letters differ by the Tukey test at $5 \%$ probability. ns=nonsignificant.

In the 2017-18 crop season, diseases (brown spot, eyespot and leaf scald) were recorded at very low severity (below than $1 \%$ ) only at the end of the crop cycle (data not showed), probably due to less favorable climatic conditions, especially linked to irregular rainfall during the reproductive stage (Figure 2). 


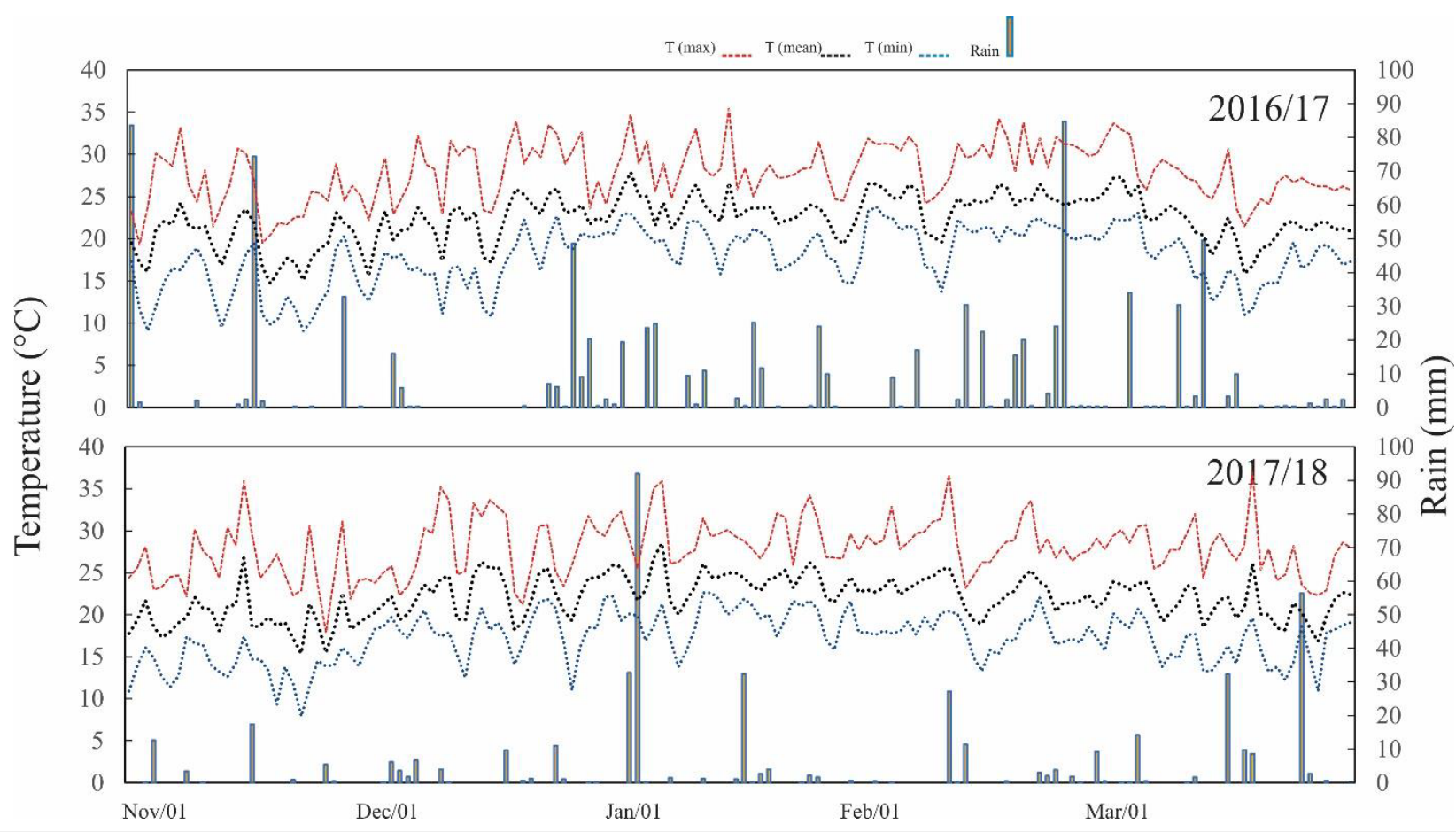

Figure 2: Rainfall, maximum (Tmax), mean (Tmean) and minimum (Tmin) temperature during the growing cycle of rice in the two seasons (2016/17 and 2017/18).

Grain yield (Figure $1 \mathrm{e}$ ) and translucent grain (Figure $1 \mathrm{~h}$ ) were only influenced by cultivars $(\mathrm{P}<0.05)$. The grain yield of the BRS Atalanta was 19\% higher than Puitá INTA CL, while translucent grain of Puitá INTA CL was 12 and 11\% higher than BRS Atalanta and BRS Querência, respectively (Figure $1 \mathrm{~h}$ ). Calcium silicate fertilization resulted in significant increase in the Si concentration in the leaves. Silicon is considered a benefic element, and its accumulation in rice plant tissue is associated to reduction in the intensity of several diseases including blast, brown spot, sheath blight and leaf scald [14]. In the Figure 3 is summarized the main procedure and results of the study, showing that the field application of calcium silicate in the Hydromorphic Planosol, one of the main soil types used for rice grow in Brazil, reduced brown spot and leaf scald severity, but the slight increases in the Si concentration in the leaves not affected significantly the grain yield and some quality attributes such as brown rice content, head rice yield and translucent grain content.

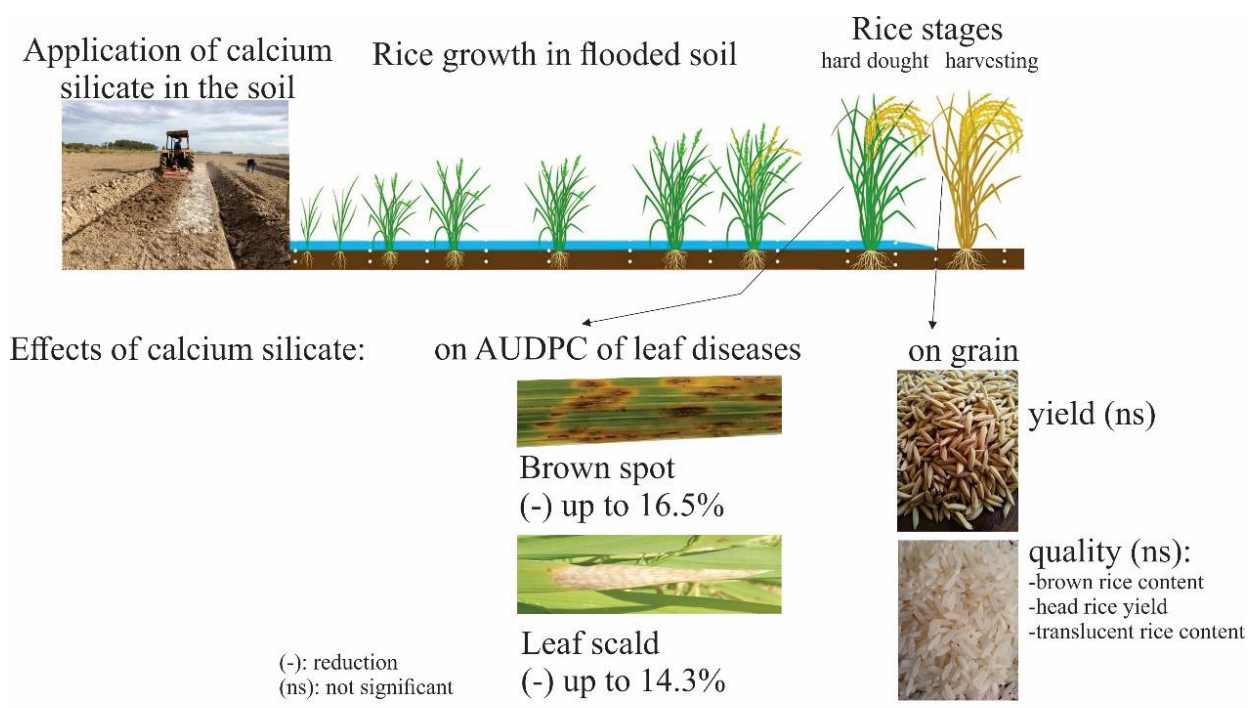

Figure 3: Procedure to incorporate calcium silicate into the soil, rice plants growth, plant development stages where the main variables were evaluated and effects of calcium silicate on the leaf diseases and on the yield and quality of grain. 
The result of this study is in agreement with previous studies conducted in arenic eutrophic Hydromorphic Planosol at two regions of Rio Grande do Sul: Central Depression and Campanha [25]. These results, contrasting to several other studies (reviewed by Rodrigues et al. [14]), may be attributed to intrinsic soil characteristics and to the adopted cultivation system (flooding) which induced alteration in the soil increasing the release of Si to the soil solution.

This hypothesis is reasoned in previous studies demonstrating that flooding the soil affect electrochemical (decrease in redox potential and changes in soil and solution $\mathrm{pH}$ ), chemical, and microbial processes increasing the availability of several elements including Si concentration in the soil solution [26-28]. However, the increase in the Si concentration in plant tissue conferred by calcium silicate fertilization was associated to the reduction in the AUDPC of the brown spot and leaf scald during the 2016-17 season. For brown spot, a minimum concentration of $\mathrm{Si}$ in plant tissue is needs to reduce the disease intensity [29]. Thus, the slight increase in the Si concentration in plants grown in soil supplied with calcium silicate reduced disease progress. However, the low severity of the diseases and their occurrence in the final stages of crop development neither affect the grain yield nor the rice quality attributes such as brown rice content, head rice yield and translucent rice content.

In the 2017-18 season, diseases were recorded at the end of crop cycle with severity below of $1 \%$. In this case, the beneficial effect of calcium silicate fertilization was not observed, either on disease severity or grain yield and its quality. Silicon has some effects on plant metabolism under normal conditions, but its benefic effects are normally observed under stress (biotic and abiotic) conditions $[30,31]$. Thus, the flooded field, reducing water deficiency to plants, and the low biotic stress, mitigated the effects of calcium silicate fertilization on rice plants. However, further studies should be performed to assess the effect of calcium silicate under conditions favorable to the disease epidemic occurring on earlier development stages and at greater intensity to measure the calcium silicate effect on grain yield and its quality.

\section{Conclusion}

Calcium silicate fertilization in Brazilian's Hydromorphic Planosol reduces the intensity of the brown spot and leaf scald. However, under low disease intensity or its occurrence during final stage of plant development, calcium silicate neither affect the grain yield nor quality parameters (brown rice content, head rice yield and translucent rice content).

\section{Acknowledgment}

The authors are thankful to the Coordination of Superior Level Staff Improvement-CAPES and PAEC OEA-GCUB-(OEA) for the financial support and for the student scholarships (Finance code 001). LJ Dallagnol (grant number 308149/2018-1) and HSS Duarte (grant number 307297/2018-7) are supported by fellowships from Brazilian National Council for Scientific and Technological Development (CNPq).

\section{Declaration of Conflict of Interest}

The authors declare that have no known competing financial interests or personal relationships that could have appeared to influence the work reported in this paper.

\section{Authors' Contributions}

Juan Felipe Rivera: conceptualization, investigation and writing-original draft, Henrique da Silva Silveira Duarte: formal analysis and writing-review \& editing, Keilor da Rosa Dorneles: investigation and writing-review \& editing, Paulo Cesar Pazdiora: investigation and writing-review \& editing, Nathan Levien Vanier: investigation and writing-review \& editing, Leandro José Dallagnol: conceptualization, supervision, writing-review \& editing.

\section{References}

1. Faostat (2020) FAO statistical database. Food and Agricultura Organization of the United Nations, Rome, Italy.

2. (2020) IBGE Instituto Brasileiro de Geografia e Estatistica, Rio de Janeiro, Brazil.

3. Streck EV, Kämpf N, Dalmolin RSD, Klamt E, Nascimento PC, et al. (2018) Solos do Rio Grande do Sul. ( $3^{\text {rd }}$ edn), Porto Alegre: Emater/RS-Ascar, p. 252.

4. Malavolta V, Parisi JJ, Takada HM, Cagnin MM (2002) Effect of different incidence levels of Bipolaris oryzae in rice seeds on physiological aspects, seed-seedling transmission and production. Summa Phytopatol 28(4): 337-341.

5. Prabhu AS, De Araújo LG, Faustina C, Berni RF (2003) Estimativa de danos causados pela brusone na produtividade de arroz de terras altas. Pesq Agropec Bras 38(9): 1045-1051.

6. SOSBAI (2016) Arroz Irrigado: Recomendações da pesquisa para o Sul do Brasil. Pelotas, Brazil.

7. Groth DE (2006) Azoxystrobin rate and timing effects on rice head blast incidence and rice grain and milling yields. Plant Dis 90(8): 1055-1058.

8. Wang Z, Jia Y, Rutger JN, Xia Y (2007) Rapid survey for presence of a blast resistance gene Pi-ta in rice cultivars using the dominant DNA markers derived from portions of the Pi-ta gene. Plant Breeding 126(1): 36-42.

9. Ma JF, Takahashi E (2002) Soil, fertilizer, and plant silicon research in Japan. Elsevier Science, Amsterdam, Netherlands.

10. Ma JF, Takahashi E (1991) Effect of silicate on phosphate availability for rice in a P-deficient soil. Plant and Soil 133: 151-155.

11. Chen D, Chen D, Xue R, Long J, Lin X, et al. (2019) Effects of boron, silicon and their interactions on cadmium accumulation and toxicity in rice plants. J Hazard Mater 367: 447-455.

12. Devrim C, Britto DT, Huynh WQ Herbert JK (2016) The role of silicon in higher plants under salinity and drought stress. Front Plant Sci 7: 1072.

13. Rios JJ, Martínez Ballesta MC, Ruiz JM, Blasco B, Carvajal M (2017) Silicon-mediated improvement in plant salinity tolerance: the role of aquaporins. Front Plant Sci 8: 948.

14. Rodrigues FA, Dallagnol LJ, Duarte HSS, Datnoff LE (2015) Silicon control of foliar diseases in monocots and dicots. In: Rodrigues FA, Datnoff LE (Eds.), Silicon and plant diseases. Springer, Switzerland, pp: 67-108.

15. Wang M, Gao LM, Dong SY, Sun YM, Shen QR, et al. (2017) Role of silicon on plant-pathogen interactions. Front Plant Sci 8: 701.

16. Meena VD, Dotaniya ML, Coumar V, Rajendiran S, Kundu S, et al. (2014) A case for silicon fertilization to improve crop yields in tropical soils. Proc Natl Acad Sci India B Biol Sci 84: 505-518. 
17. Notteghem J (1981) Cooperative experiment on horizontal resistance to rice blast. Blast and upland rice: report and recommendations from the meeting for international collaboration in upland rice improvement. International Rice Research Institute, Los baños, Philippines, pp: 43-51.

18. Schwanck AA, Del Ponte EM (2014) Accuracy and reliability of severity estimates using linear or logarithmic disease diagram sets in true colour or black and white: a study case for rice brown spot. J Phytopathol 162(10): 670-682.

19. IRRI (2002) Standard evaluation system for rice. International Rice Research Institute. p. 56.

20. Rivera JF, Duarte HSS, Furtado EB, Dallagnol LJ (2020) A standard area diagram set for severity assessment of eyespot on rice. Austral Plant Pathol 49: 367-371.

21. Shaner G, Finney R (1977) The effect of nitrogen fertilization on the expression of slow- mildewing resistance in Knox wheat. Phytopathology 67: 1051-1056.

22. BRASIL (2009) Ministério da Agricultura, Pecuária e Abastecimento. Regras para análise de sementes. MAPA/ACS, Brasília.

23. Korndörfer GH, Pereira CS, Nolla A, Korndörfer GH, Pereira A (2004) Análise de Silício: Solo, Planta e Fertilizante. Uberlândia MG, Universidade Federal de Uberlândia, Brazil.
24. R Core Team (2020) The R Project for statistical computing.

25. Marchezan E, Villa SCC, Marzari V, Korndorfer GH, Do Santos FM (2004) Aplicação de silício em arroz irrigado: efeito nos componentes da produção. Bioscience J 20(3): 125-131.

26. Liang Y, Nikolic M, Bélanger R, Gong H, Song A (2015) Silicon uptake and transport in plants: physiological and molecular aspects. In: Silicon in agriculture. Springer, Dordrecht, Netherlands, pp: 69-82.

27. Tubaña BS, Heckman JR (2015) Silicon in soils and plants. In: Rodrigues FA, Datnoff LE (Eds.), Silicon and Plant Diseases. Springer, Switzerland, pp: 7-51.

28. Witt C, Haefele SM (2005) Paddy soils. In: Daniel H (Ed.), Encyclopedia of soils in the environment. Elsevier, Oxford, England, pp: 141-150.

29. Dallagnol L, Rodrigues FA, Mielli MVB, Ma JF, Datnoff LE (2009) Defective active silicon uptake affects some components of rice resistance to brown spot. Phytopathology 99: 116-121.

30. Debona D, Rodrigues FA, Datnoff LE (2017) Silicon's role in abiotic and biotic plant stresses. Annu Rev Phytopathol 55: 85-107.

31. Frew A, Weston LA, Reynolds OL, Gurr GM (2018) The role of silicon in plant biology: a paradigm shift in research approach. Ann Bot 121: 1265-1273.

For possible submissions Click below:

Submit Article 